\title{
Effect of Magnetisation of Sulphate Water in Concrete
}

\author{
G.Pramod Kumar ${ }^{1}$, D.Prudvi Reddy ${ }^{2}$ and A.Venkat Reddy ${ }^{3}$ \\ ${ }^{1,2,3}$ CVR College of Engineering, Department of Civil Engineering, Hyderabad, INDIA \\ Email: ${ }^{1}$ gpramodkumar3@gmail.com, ${ }^{2}$ prudhvi.reddy@cvr.ac.in, ${ }^{3}$ venkat.reddy@cvr.ac.in
}

\begin{abstract}
This paper presents a technique which can make water containing salts beyond limits prescribed by IS-456:2000 suitable for a concrete mix called Magnetisation of water. The prominent salts present in sea water that effect concrete are Chlorides and Sulphates. Magnetisation effect on water rich in sulphates which was used in concrete has been studied. The magnetisation of salt water changes the nanostructure of water molecule which helps in increase of strength of concrete. The compressive strength test results conducted on concrete cubes shown a definite increase in compressive strength of concrete by using magnetised water in concrete mix. This method is helpful in making unfit water fit for concrete mix. There by, this method can be adopted when there is a crisis of potable water.
\end{abstract}

Index Terms-Magnetisation, Sulphate water, Compressive Strength, Workability, Magnetic water, Normal water.

\section{INTRODUCTION}

Scarcity of water is one of the major problems going to be faced by the mankind in the near future. Lack of sufficient quantity of water resources within a region is defined as "Water scarcity". The day-to-day need for water has been increasing tremendously all over the world and India, being a country with such a huge population, is already facing problems regarding the availability of fresh water for drinking and household purposes. As water is becoming scarce to meet the daily domestic needs of the living beings, use of potable water for concrete mix should be substituted by an alternate source of water. Hence water which is rich in sulphates has been thought of as an alternative.

Sea water is about $97 \%$ of the total water present on the earth surface. Using sea water (rich in salts) directly for mixing in concrete is not suggested as the deterioration of the strength of concrete takes place when we go for a long term basis. The loss of strength is about $10-15 \%$. Also, the sea water has a $\mathrm{pH}$ range of 7.4-8.4. If the $\mathrm{pH}$ is less than 11 , corrosion of reinforcing steel becomes a major problem. Therefore in such cases, alkalinity inside the concrete has to be maintained by the hydration of the cement. One of the main chemical constituents of seawater is sulphate ions.

Permissible Limit as per IS - 456:2000, Sulphates $400 \mathrm{mg} / 1$
Setting time of cement is adversely affected by adding water with sulphate content above the permissible limit as the rate of hydration of cement compounds is highly influenced. Certain inherent properties of water would be changed when it is exposed to a magnetic field. This process is called Magnetisation of water and the output product is called Magnetised water. These anomalous properties of water are unique for water and may result in many variations of macroscopic properties [2], [3].

\section{Reasearch Methodology}

$\mathrm{C}_{3} \mathrm{~A}$ and $\mathrm{C}_{4} \mathrm{AF}$ contribute to the setting characteristics of cement paste. When water with high sulphate content is added, during hydration, aluminates react with sulphates much quicker than the other compounds and form either calcium sulphoaluminate (high sulphate form, ettringite) or calcium aluminate mono sulphate (low sulphate form). As calcium aluminate compounds are being converted to calcium sulphoaluminate compounds, rapid setting of cement paste is prevented and hence the setting time of cement is considerably increased [8].

The chemical reactions between sulphate and the various cement hydrates are as follows -

(a) Crystalline Calcium Hydroxide $\left(\mathrm{Ca}(\mathrm{OH})_{2}\right)$ present in the hydrated cement is found to react with sodium and ammonium sulphates which results in the formation of gypsum $\left(\mathrm{CaSO}_{4} \cdot 2 \mathrm{H}_{2} \mathrm{O}\right)$

$\mathrm{Na}_{2} \mathrm{SO}_{4}+\mathrm{Ca}(\mathrm{OH})_{2}+2 \mathrm{H}_{2} \mathrm{O} \rightarrow 2 \mathrm{NaOH}+\mathrm{CaSO}_{4} \cdot 2 \mathrm{H}_{2} \mathrm{O}$

$\left(\mathrm{NH}_{4}\right)_{2} \mathrm{SO}_{4}+\mathrm{Ca}(\mathrm{OH})_{2}+2 \mathrm{H}_{2} \mathrm{O} \rightarrow 2 \mathrm{NH}_{4} \mathrm{OH}+\mathrm{CaSO}_{4} \cdot 2 \mathrm{H}_{2} \mathrm{O}$

Sodium ions form soluble hydroxides while Ammonium ions produce volatile hydroxides.

(b) Sulphates further react with the calcium aluminate/calcium aluminate monosulphate hydrates present in the hardened cement and form ettringite. $3 \mathrm{CaO} \cdot \mathrm{Al}_{2} \mathrm{O}_{3} \cdot \mathrm{CaSO}_{4} \cdot 12 \mathrm{H}_{2} \mathrm{O}+2 \mathrm{Na}_{2} \mathrm{SO}_{4}+2 \mathrm{Ca}(\mathrm{OH})_{2}+2 \mathrm{H}_{2} \mathrm{O}$ $\rightarrow 3 \mathrm{CaO} \cdot \mathrm{Al}_{2} \mathrm{O}_{3} \cdot 3 \mathrm{CaSO}_{4} \cdot 32 \mathrm{H}_{2} \mathrm{O}+4 \mathrm{NaOH}$ (Ettringite)

(c) $\mathrm{Ca}(\mathrm{OH})_{2}$ of cement paste reacts with $\mathrm{MgSO}_{4}$ to form gypsum.

$\mathrm{MgSO}_{4}+\mathrm{Ca}(\mathrm{OH})_{2}+2 \mathrm{H}_{2} \mathrm{O} \rightarrow \mathrm{CaSO}_{4} \cdot 2 \mathrm{H}_{2} \mathrm{O}+\mathrm{Mg}(\mathrm{OH})_{2}$

Calcium silicate hydrates are decomposed by $\mathrm{MgSO}_{4}$ resulting in the formation of high amount of gypsum.

$3 \mathrm{MgSO}_{4}+3 \mathrm{CaO} .2 \mathrm{SiO}_{2} \cdot 3 \mathrm{H}_{2} \mathrm{O}+8 \mathrm{H}_{2} \mathrm{O} \rightarrow 3\left(\mathrm{CaSO}_{4} \cdot 2 \mathrm{H}_{2} \mathrm{O}\right)+3$ $\mathrm{Mg}(\mathrm{OH})_{2}+2 \mathrm{SiO}_{2} \cdot \mathrm{H}_{2} \mathrm{O}$

The quantity of $\mathrm{Ca}(\mathrm{OH})_{2}$ is getting reduced and the product formed, $\mathrm{Mg}(\mathrm{OH})_{2}$ has very low solubility resulting in the decrease of $\mathrm{pH}$ value. Alkalinity as well as stability of $\mathrm{C}-\mathrm{S}-\mathrm{H}$ gel is reduced and decomposition continues progressively. Ettringite and gypsum are highly 
voluminous compounds which result in expansion and cracking of concrete with subsequent loss in strength [8].

\section{Experimental Procedure}

\section{A. Materials}

\section{Magnets}

In the present investigation work, the Magnets were obtained from scientific store. The shapes of magnets are rounded. We found the strength of magnet by Gauss meter. Three types of strength magnets we used. The average magnetic strength of four magnets is 985 gauss.

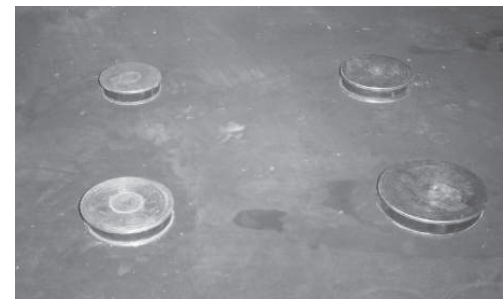

Figure 1: Magnets Used For Magnetising Water

\section{B.Water}

Water with SULPHATE content of 250ppm was taken for mixing of concrete only. Beakers of 1 liter capacity filled with water are place above the magnets shown in fig. 1 for one day (24 hours) to obtain magnetised water [2].

\section{Aggregates}

Coarse aggregate used in the investigations was of two sizes viz. $20 \mathrm{~mm}$ and $12 \mathrm{~mm}$. The coarse aggregate was procured from the local available plants. Fine sand was obtained from a local purveyor. IS 2386 specifications have been followed for testing physical properties of aggregates which are presented in Table 1 .

TABLE 1

Physical Properties of Aggregates

\begin{tabular}{|c|c|c|c|}
\hline Properties & $\begin{array}{c}\text { Coarse } \\
\text { Aggregate } \\
(\mathbf{2 0 m m})\end{array}$ & $\begin{array}{c}\text { Coarse } \\
\text { Aggregate } \\
(\mathbf{1 2 m m})\end{array}$ & Fine Aggregate \\
\hline $\begin{array}{l}\text { Fineness } \\
\text { modulus }\end{array}$ & 7.228 & 5.314 & 2.88 \\
\hline $\begin{array}{l}\text { Specific } \\
\text { gravity }\end{array}$ & 2.6 & 2.58 & 2.6 \\
\hline $\begin{array}{l}\text { Bulk density } \\
\text { in loose state }\end{array}$ & $1361 \mathrm{~kg} / \mathrm{m}^{3}$ & $1332 \mathrm{~kg} / \mathrm{m}^{3}$ & $1550 \mathrm{~kg} / \mathrm{m}^{3}$ \\
\hline
\end{tabular}

\section{Cement}

Locally available 53 grade Ordinary Portland Cement (OPC) of Ultratech brand is used in the present investigation for all concrete mixes. The cement procured is tested for physical and chemical requirements in accordance with IS 12269-1987 and the results are shown in Table 2.
TABLE 2

Physical Properties of Cement Used In The Mix

\begin{tabular}{|c|c|}
\hline Properties & Test Result \\
\hline Normal consistency & $30 \%$ \\
\hline Specific gravity & 3.02 \\
\hline Initial setting time (minutes) & $55 \mathrm{~min}$ \\
\hline Final setting time (minutes) & $560 \mathrm{~min}$ \\
\hline Fineness & $3 \%$ \\
\hline Soundness (Le-chatelier's method) & $2 \mathrm{~mm}$ \\
\hline Compressive strength (28 days) & $54.7 \mathrm{~N} / \mathrm{mm}^{2}$ \\
\hline
\end{tabular}

\section{E. Mix Composition}

M20 mix has been designed as per the procedure given in IS: 10262-2009. The quantities of materials required per one cubic meter of concrete obtained are given in Table 3 as per mix proportion 1: 2.32: $3.77: 0.55$.

TABLE 3

TRIAL MiX PROPORTIONS For 1M3 OF CONCRETE

\begin{tabular}{|c|c|c|c|c|c|}
\hline \multirow{2}{*}{ Grade } & \multicolumn{4}{|c|}{ Materials $\left(\mathrm{kg} / \mathrm{m}^{3}\right)$} & \multirow{2}{*}{ Water/cement } \\
\cline { 2 - 5 } & Cement & F.A. & C.A. & Water & \\
\hline M 20 & 310 & 718 & 1167 & 170.5 & 0.55 \\
\hline
\end{tabular}

\section{Preparation of Test Specimen}

In the present investigation, machine mixing was adopted. Various ingredients of concrete namely cement, fine aggregate, coarse aggregate and water are added as per the weights obtained from mix design. The required quantity of cement content is thoroughly blended with hand and then all the ingredients are poured into the pan mixer. The materials are thoroughly mixed in their dry condition before water is added. Then calculated amount of water is gradually added and wet mixing is done until a mixture of uniform colour is achieved. Generally the mixers are designed to run at a speed of 15 to 20 revolutions per minute. For proper mixing, it is seen that about 25 to 30 revolutions are required. Mixing was done in batches. In each batch the amount of materials required to prepare six test specimens are weighed, based on the designed mix proportions of each concrete mix used. Before casting the specimens, workability of the mixes were found out by slump test. For casting the test specimen, standard size of $150 \times 150 \times 150 \mathrm{~mm}$ cast iron metal moulds are used. The moulds have been cleaned to remove the dust particles and mineral oil is applied on all the internal sides of the moulds. Then thoroughly mixed concrete is placed in the moulds and vibrated by pin vibrator. Finally the top surface is troweled and made smooth.

After 24 hours, the specimens are demoulded and placed in clean water for curing. Cubes are allowed for curing in the curing tank until the day of testing. Before the cubes are tested for compressive strength, they are made surface dry after removing from the curing tank. Tests are done for determining the 7, 14, 21 and 28 days compressive strength. A $3000 \mathrm{kN}$ capacity CTM was used to determine the compressive strength of concrete. 


\section{RESULTS}

Workability test is conducted for different concrete mixes with Normal water and Magnetic water and the slump values are listed in Table 4.

TABLE 3

WORKABILITY OF NWC, NSW AND MSW

\begin{tabular}{|c|c|c|}
\hline GRADE & Type of concrete & Workability \\
\hline \multirow{4}{*}{ M20 } & Normal water concrete & 50 \\
\cline { 2 - 3 } & Normal Sulphate water Concrete & 50 \\
\cline { 2 - 3 } & $\begin{array}{c}\text { Magnetised Sulphate water } \\
\text { Concrete }\end{array}$ & 55 \\
\hline
\end{tabular}

From Table 4, it is clear that there is very less change in consistency of concrete for all the concrete mixes but however magnetised water is showing more workability compared to normal water.

Table 5 gives compressive strengths of NWC, NSWC and MSWC. Fig 2 shows the variation of compressive strengths of NWC, NSWC concrete and MSWC concrete with age (in days) up to 28 days.

TABLE 5

COMPRESSIVE STRENGTH OF DIFFERENT CONCRETE

\begin{tabular}{|c|c|c|c|}
\hline $\begin{array}{c}\text { Age of sample } \\
\text { (Days) }\end{array}$ & NWC & NSWC & MSWC \\
\hline 7 & 18.76 & 15.62 & 22.82 \\
\hline 14 & 24.41 & 18.79 & 26.97 \\
\hline 21 & 27.25 & 20.82 & 30.13 \\
\hline 28 & 28.29 & 23.81 & 33.96 \\
\hline
\end{tabular}

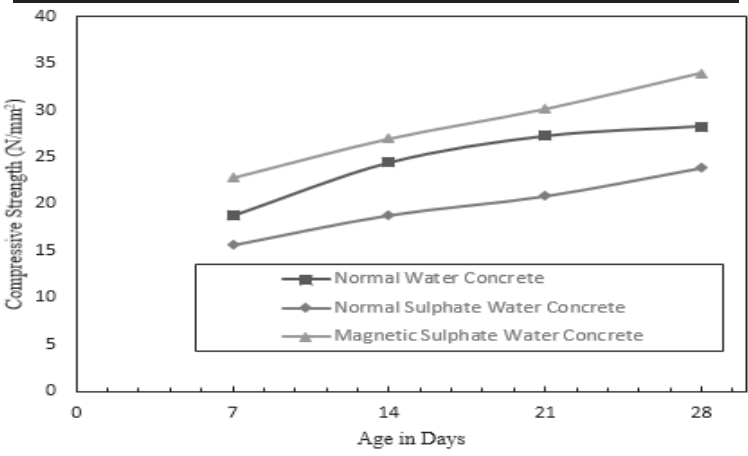

Figure 2: Compressive Strength of Different Concrete

There is a significant increase in compressive strength of MSWC concrete when compared with NSWC. The reason is in the case of MSWC, the rate of hydration is more i.e., the number of cement particles hydrated increases due to the increase in the specific surface area of water, (caused by forming smaller size and higher number of water clusters due to magnetisation). Sulphate reaction is slow when compared to the rate of hydration. As a result, the number of cement compounds reacting with sulphate will be less when compared with NSWC and hence fewer amounts of gypsum, magnesium hydroxide and ettringite is formed. Ettringite and gypsum are expansive in nature leading to the loss of strength of concrete. The quantity of $\mathrm{Ca}(\mathrm{OH})_{2}$ is getting reduced and the product formed, $\mathrm{Mg}(\mathrm{OH})_{2}$ has very low solubility resulting in the decrease of $\mathrm{pH}$ value. Alkalinity as well as stability of C-S-H gel is reduced and decomposition continues progressively. Ettringite and gypsum are highly voluminous compounds which result in expansion and cracking of concrete with subsequent loss in strength.

$\mathrm{MgSO}_{4}+\mathrm{Ca}(\mathrm{OH})_{2}+2 \mathrm{H}_{2} \mathrm{O} \rightarrow \mathrm{CaSO}_{4} \cdot 2 \mathrm{H}_{2} \mathrm{O}+\mathrm{Mg}(\mathrm{OH})_{2}$ $3 \mathrm{MgSO}_{4}+3 \mathrm{CaO} .2 \mathrm{SiO}_{2} \cdot 3 \mathrm{H}_{2} \mathrm{O}+8 \mathrm{H}_{2} \mathrm{O} \rightarrow 3\left(\mathrm{CaSO}_{4} \cdot 2 \mathrm{H}_{2} \mathrm{O}\right)+$ $3 \mathrm{Mg}(\mathrm{OH})_{2}+2 \mathrm{SiO}_{2} \cdot \mathrm{H}_{2} \mathrm{O}$

\section{CONCLUSION}

Magnetisation results in higher workability than that of normal water.

At 28 days, the compressive strength test results show that there is a decrease in strength of about $15.82 \%$ in NSWC concrete when compared with NWC. The strength of the cubes made with MSWC concrete is $45.29 \%$ higher than those made with NSWC concrete. Comparing with NWC, the strength of MSWC increased by about $20.03 \%$.

\section{FUTURE SCOPE}

The same investigation of the influence of magnetic salt(Sulphates) water on compressive strength of concrete can be extended by varying the magnetic strength. The present investigation can be extended to make concrete of higher grades. Effects of magnetic saltwater on durability of concrete can be carried out. Nanostudies on the structure of water can be carried out.

\section{REFERENCES}

[1] Ashrae, "Efficiency of physical water treatments in controlling calcium scale accumulation in recirculation open cooling water system", Research project No.1155TRP,submitted at department of mechanical engineering and mechanics, Drexel University, Philadelphia, May 2002, pp.1-226.

[2] B.S.K Reddy, Vaishali.G.Ghorpade and H.Sudarsana Rao, (2013). "Effect of magnetic field exposure time on compressive strength of concrete", International Journal of Advanced Engineering and Technology, Vol. IV/III, P.120122.

[3] B.S.K Reddyet al (2014) studied "the effect of addition of magnetic water on workability, strength and mechanical properties of concrete"

[4] M L Gambhir, "Concrete Technology" (Third Edition), Tata McGraw-Hill publications, 1986, pp.1-571.

[5] M.S Shetty, "Concrete Technology theory and practice" (First Edition), S.Chand publications, 1982, pp.1-605.

[6] Nan Su, Yeong-Hwa. Wu and Chung-Yo Mar., "Magnetic water on the engineering properties ofconcrete containing granulated blast furnace slag", Journal of Cement and Concrete Research, Vol.30, 2000, pp. 599-605.

[7] N.KrishnaRaju, "Design of concrete mixes" (Fourth Edition), CBS publications, 2002, pp.1-283.

[8] Sunil Kumar and C.V.S. Kameswara Rao "effect of sulfates on the setting time of cement and strength of concrete", Department of Civil Engineering, Harcourt Butler Technological Institute, Kanpur. 